\title{
Preserving Platelet Count for a Diagnosed Patient with Acute Myeloid Leukemia on Hydroxychloroquine: A Case Report
}

\author{
Dina K. Farrag ${ }^{1}$ and Nagwa A. Sabri ${ }^{*}$ \\ ${ }^{1}$ Police Hospital, El-Agouza, Giza, EGYPT \\ ${ }^{2}$ Clinical Pharmacy Department, Faculty of Pharmacy, Ain-Shams University, Cairo, Egypt
}

\begin{abstract}
A female patient (N.H.) 70-years-old, married and having two children was admitted to the oncology department EI Agouza police Hospital, Egypt on July 2018, She was diagnosed with Relapsed Acute Myeloid Leukemia (AML), with the following clinical presentation; fever, shortness of breath, frequent coughing, night sweats, joint pain and bruising, her ultrasound examination revealed mild splenomegaly, moreover, there was an evidence of endocrinology diagnosis with Type II Diabetes and Grade III Obesity.

Concerning the medication history, she had started Decitabine (Dacogen ${ }^{\circledR}$ ) 3 months ago to be continued for another 3 months to follow her chemotherapeutic plan, also was on hydroxychloroquine and leflunomide (Avara $\left.{ }^{\circledR}\right)$ past year for her rheumatoid arthritis, her laboratory results showed very low platelet count 50,000/mm cub, but normal complement C3 and C4 levels, $90 \mathrm{mg} / \mathrm{dl}$ and $30 \mathrm{mg} / \mathrm{dl}$ respectively.

It was concluded that the use of Hydroxychloroquine in patients diagnosed with acute myeloid leukemia also suffering rheumatoid arthritis, may decrease their platelet count and increase the risk of bleeding, therefore, it is recommended to prescribe an alternative disease-modifying anti-rheumatic drugs (DMARDs).
\end{abstract}

\section{Keywords}

Acute Myeloid leukemia, Hydroxychloroquine, Decitabine chemotherapy, Rheumatoid arthritis, thrombocytopenia

\section{Introduction}

Acute Myeloid leukemia (AML) is a type of cancer starting from the myeloid line of blood cells, where tumor cells within the bone marrow grow rapidly interfering with the assembly of normal blood cells [1]. Symptoms may include shortness of breath, fatigue cause of dropping of red blood corpuscle count also bruising or bleeding, petechiae (flat, pin-head sized spots under the skin caused by bleeding) due to lack of platelets, also increased risk for infection, symptoms seem like those of influenza, fever, fatigue, weight loss or loss of appetite, bone and joint pain were also present [2]. Since AML progresses rapidly, it's typically fatal within weeks or months if left untreated, moreover, previous chemotherapy exposure and radiation are risk factors for developing it, where, the danger is highest about three to 5 years after chemotherapy, also specific genetic abnormalities as GATA2 deficiency-induced Acute Myeloid leukemia, it could first appear in children or adults [3]. This specific genetic mutations within the cancer cells may guide therapy and determine how long that person is likely to survive [4]. Acute Myeloid leukemia affected about 1 million case, resulted in 147,000 deaths globally in 2015 , it most typically occurs in older adults, men are more susceptible than women. The five-year survival rate are about
$35 \%$ in people $<60$-years-old and $10 \%$ in people $>60$-yearsold [4]. Diagnosis is often demonstrated as an abnormal result on an entire blood count the primary clue while an excess for abnormal white blood cells may be a common finding and an isolated decreases in platelets count and red blood cells [5]. Leukemic blasts are present on examination of the peripheral blood smear while a definitive diagnosis requires an adequate bone marrow aspiration and biopsy also ruling out vitamin B12, folic acid and copper deficiency [6]. Acute Myeloid leukemia is initially treated with chemotherapy in order to achieve remission, where, patients may continue receiving an additional chemotherapy, radiation therapy, or a stem cell transplantation [7].

*Corresponding author: Nagwa A Sabri, PhD, Professor and Head of Clinical Pharmacy Department, Faculty of Pharmacy, Ain-Shams, Cairo, Egypt

Accepted: October 31, 2020

Published online: November 02, 2020

Citation: Farrag DK, Sabri NA (2020) Preserving Platelet Count for a Diagnosed Patient with Acute Myeloid Leukemia on Hydroxychloroquine: A Case Report. Advances Leuk Res Treat 2(1):25-27 
Citation: Farrag DK, Sabri NA (2020) Preserving Platelet Count for a Diagnosed Patient with Acute Myeloid Leukemia on Hydroxychloroquine: A Case Report. Advances Leuk Res Treat 2(1):25-27

Table 1: Blood cell count before clinical pharmacists' intervention.

\begin{tabular}{|l|l|l|l|}
\hline Test Name & Result & Unit & Reference Range \\
\hline Haemoglobin & 7.2 & $\mathrm{~g} / \mathrm{dl}$ & $12.5-17.5$ \\
Red blood cell count & 2.64 & Millions/cmm & $4.5-5.9$ \\
Platelet Count & 50 & Thousands/cmm & $150-450$ \\
White blood cell count & 30 & Thousands/cmm & $4-10$ \\
Neutrophils & 1.2 & $\times 10^{\wedge}$ - $/ \mathrm{L}$ & $2-7$ \\
\hline
\end{tabular}

Table 2: Treatment Recommendations.

\begin{tabular}{|c|c|c|c|}
\hline Drug name & Dosage Form & Dose Frequency & Timing \\
\hline Decitabine $\left(\right.$ Dacogen $\left.^{\circledR}\right)$ IV & Vial & $20 \mathrm{mg} / \mathrm{m}^{2}$ for 5 days & Every 28 days \\
\hline Hydroxychloroquine 200 mg & Tab & Twice daily & With Food \\
\hline Leflunomide 20 mg $\left(\right.$ Avara $^{\circledR}$ ) & Tab & Once daily & Without regard to Meals \\
\hline Rosuvastatin $10 \mathrm{mg}$ (crestor $10^{\circledast}$ ) & Tab & Once daily & With or Without Food \\
\hline Glimepride 2 mg $\left(\right.$ Amaryl $^{\circledR}$ ) & Tab & Once daily & With breakfast \\
\hline Pantoprazole 40 mg (Controloc ${ }^{\circledR}$ ) & Tab & Once daily & With or Without Food \\
\hline Valsartan 80 mg (Tareg $\left.{ }^{\circledR}\right)$ & Tab & Once daily & With or Without Food \\
\hline Paracetamol $500 \mathrm{mg}$ & Tab & Every 6 hrs & With or Without Food \\
\hline
\end{tabular}

Table 3: Blood cell count after clinical pharmacists' intervention.

\begin{tabular}{|l|l|l|l|}
\hline Test Name & Result & Unit & Reference Range \\
\hline Haemoglobin & 10.2 & g/dl & $12.5-17.5$ \\
Red blood cell count & 3.64 & Millions/cmm & $4.5-5.9$ \\
Platelet Count & 150 & Thousands/cmm & $150-450$ \\
White blood cell count & 12 & Thousands/cmm & $4-10$ \\
Neutrophils & 2.2 & $\times 10^{\wedge 9 / L}$ & $2-7$ \\
\hline
\end{tabular}

\section{Case Report}

A female patient (N.H.) 70-years-old, married and having two children was admitted to the oncology department El Agouza police Hospital,Egypt on July 2018, She was diagnosed with Relapsed Acute Myeloid Leukemia ( $A M L)$, with the following clinical presentation; fever, shortness of breath, frequent coughing, night sweats, joint pain and bruising, her ultrasound examination revealed mild splenomegaly, moreover, there was an evidence of endocrinology diagnosis with Type II Diabetes and Grade III Obesity (BMI $=46$, calculated as [weight $(\mathrm{kg})] /$ height $\left(\mathrm{m}^{2}\right)$ ], waist circumference $=90 \mathrm{~cm}$, measured halfway between xiphoid and umbilical appendix, waisthip ratio WHR) $>0.95$, calculated as waist circumference/hips circumference (measured between the two trochanters), her complete blood count results as shown in Table 1 , where $\mathrm{Hb}=$ $7.2 \mathrm{~g} / \mathrm{dL}, \mathrm{Ht}=30 \%$, low platelets count of $50,000 / \mathrm{mm}$ cub and RBCs count $=2.64$ Millions $/ \mathrm{cmm}$ but an increased number of Leucocytes, $50,000 / \mathrm{mm}$ cub, Neutrophils $=1.2 \times 10^{9} / \mathrm{L}$, also high Cholesterol $=250 \mathrm{md} / \mathrm{dL}$, where complement $\mathrm{C} 3$ and C4 levels are $90 \mathrm{mg} / \mathrm{dl}$ and $30 \mathrm{mg} / \mathrm{dl}$ respectively.

Patient has started Azacitidine (Vidaza ${ }^{\circledR}$ ) 6 months ago before relapse of Acute Myeloid Leukemia, recommendation for treatment as shown in Table 2, was to start Decitabine (Dacogen ${ }^{\circledR}$ ) IV at a dose of $20 \mathrm{mg} / \mathrm{m}^{2}$ for 5 days every 28 days until disease progression or unacceptable toxicity, follow up every six months she already finished 3 cycles, patient was also on Hydroxychloroquine $200 \mathrm{mg}$ and Leflunomide (Avara $20^{\circledR}$ ) past year for rheumatoid arthritis, Rosuvastatin (crestor $10^{\circledR}$ ), Glimepride (Amaryl $2^{\circledR}$ ), Valsartan (Tareg $80^{\circledR}$ ), Pantoprazole 20 (Controloc $20^{\circledR}$ ) and Paracetamol $500 \mathrm{mg}$.

\section{Discussion}

It is worthy to mention that, the patient was suffering other comorbidities beside AML which are; hypertension, hyperglycemia, rheumatoid arthritis, in addition to obesity as a risk factor to many diseases. In addition, reported low platelet counts after 3 cycles of prescribed chemotherapy, may increase the risk of bleeding, immunosuppressant effects leading to fever and infection which interfere with the patient chemotherapy schedule and treatment compliance [8].

From the above reported data, an intervention must be done for the investigation of the main cause of decreased platelets count in order to resume her chemotherapy regimen. The clinical pharmacists' intervention was to stop hydroxychloroquine as a treatment for rheumatoid arthritis and continue on leflunomide as prescribed, after this action, it was reported that patient's platelet count increases three folds as shown in Table 3, which can be explained on the basis that one of the side effects of hydroxychloroquine include thrombocytopenia [9]. 
The decision to stop administration of hydroxychloroquine as a risk/benefit ratio would be favorable in order to avoid bleeding, also the patient was advised to follow a healthy diet and avoid unpasteurized beverages as fruit juice, milk and raw milk yogurt to avoid any source of infection [9].

\section{Conclusion}

Hydroxychloroquine as a disease-modifying antirheumatic drug (DMARD) used for treatment of rheumatoid arthritis should be used with caution for diseases accompanied by thrombocytopenia as Acute Myeloid leukemia in order to a avoid high risk of bleeding resulting from impressive low platelet cell count, also higher proportions of patients with low platelets count are needed to emphasize the use of another disease-modifying antirheumatic drug (DMARD) would be more beneficial.

\section{Statement of Compliance and Clinical Trial Transparency}

The patient in this report signed an informed consent for her participation in this trial. All authors declare that the study was conducted in accordance with all applicable ethical standards.

\section{Competing Interests}

None.

\section{Funding}

This research did not receive any specific grant from Funding agencies in the public, commercial, or not-for-profit sectors.

\section{Author Contributions}

Dina K. Farrag: Investigation, writing original draft and data curation. Nagwa A. Sabri: Supervision, review and editing the case report.

\section{References}

1. Vakiti A and Mewawalla P (2019) Acute myeloid In StatPearls.

2. (2017) Adult Acute Myeloid Leukemia Treatment. National Cancer Institute.

3. (2014) What are acute myeloid leukemia risk factors? American Cancer Society.

4. Kayser S, Levis MJ (2014) FLT3 tyrosine kinase inhibitors in acute myeloid leukemia: Clinical implications and limitations. Leuk Lymphoma 55: 243-255.

5. Aitelli C, Wasson L, Page R (2004) Pernicious anemia: presentations mimicking acute leukemia. South Med J 97: 295-297.

6. Zuo Z, Polski JM, Kasyan A, et al, (2010) Acute erythroid leukemia. Arch Pathol Lab Med 134: 1261-1270.

7. Döhner H, Weisdorf DJ, Bloomfield CD (2015) Acute Myeloid Leukemia. N Engl J Med 373: 1136-1152.

8. Cheg MJ, Hourigan CS, Smith TJ (2014) Adult Acute Myeloid Leukemia Long-term Survivors. J Leuk (Los Angel) 2: 26855.

9. Milligan DW, Grimwade D, Cullis JO, et al. (2006) Guidelines on the management of AML in adults. Br J Haematol 135: 450-474.

DOI: $10.36959 / 486 / 326$

Copyright: (C) 2020 Farrag DK, et al. This is an open-access article distributed under the terms of the Creative Commons Attribution License, which permits unrestricted use, distribution, and reproduction in any medium, provided the original author and source are credited. 